PF 2019 (LXXIII): 11-31

\author{
MICHALINA BIERNACKA \\ Zakład Lingwistyki \\ Stosowanej i Kulturowej \\ Uniwersytet Łódzki \\ ul. Pomorska 171/173, 90-236 Łódź \\ tel. (+48) 426645298 \\ e-mail: michalina.biernacka@uni.lodz.pl
}

\title{
REALIZACJE TZW. SAMOGŁOSEK NOSOWYCH - AUDYTYWNO-AKUSTYCZNA OCENA WYMÓWIEŃ UCZĄCYCH SIĘ JĘZYKA POLSKIEGO JAKO OBCEGO Z POZIOMU A1
}

SŁOWA KLUCZOWE: tzw. samogłoski nosowe, nauczanie języka polskiego jako obcego

KEYWORDS: nasal vowels, teaching Polish as a foreign language

\author{
REALIZATIONS OF THE NASAL VOWELS - HOW TEACHERS ASSESS \\ THE PRONUNCIATION IN LEARNERS OF POLISH AS A FOREIGN LANGUAGE \\ AT THE A1 LEVEL
}

\begin{abstract}
The majority of contemporary studies in phonetics, which are based on objective acoustic research, adopt the asynchronic, two, three or four-segmental articulation of vowels representing graphemes $\langle a\rangle\rangle$ and $\langle e ̨\rangle$. Even so, it is still quite common to teach the synchronic pronunciation to foreigners, e.g. in a word-final position or before fricative, non-palatal sounds. The author analyzes how teachers of Polish as a foreign language perceive various pronunciations of the so-called nasal vowels (in 23 randomly chosen level A1 students of 18 nationalities) and proposes yet another verification of phonetic requirements for foreigners speaking Polish.
\end{abstract}

\section{Wprowadzenie}

Lektorzy języka polskiego jako obcego (jpjo), odpowiadając na pytanie kierowane do lektorów języka polskiego jako obcego (jpjo), które polskie samogłoski 
percepcyjnie bądź/i artykulacyjnie uchodzą za najtrudniejsze do opanowania przez cudzoziemców uczących się języka polskiego, z reguły w pierwszej kolejności wymieniają tzw. samogłoski nosowe ${ }^{1}$, które nota bene ogólnie są uznawane za rzadkie w językach świata. Jak pokazują moje dziesięcioletnie doświadczenia w prowadzeniu zajęć z nauczania wymowy obcokrajowców na specjalizacji glottodydaktycznej oraz logopedii na Uniwersytecie Łódzkim, przekonanie takie panuje zwłaszcza wśród adeptów glottodydaktyki, przyszłych nauczycieli języka polskiego jako obcego. Podobne opinie wyrażają również uczący się języka polskiego cudzoziemcy. Samogłoski nosowe należą do dźwięków, które - nauczane w korelacji z ortografią - są przeważnie długo opanowywane ze względu na liczbę obowiązujących reguł ich zapisu. Jeśli zaś chodzi o samą ich wymowę, to nawet na poziomie A nie przysparzają aż tylu problemów, co chociażby szereg [i / y / e] obejmujący głoski bliskie sobie pod względem artykulacyjno-brzmieniowym. Mimo to, ze względu na wariantywność, samogłoski nosowe są trudne dla wielu obcokrajowców, niezależnie od ich języków pierwszych, dlatego wpisać je można do inwentarza tzw. miejsc trudnych polszczyzny w zakresie systemu wokalicznego (Biernacka 2016). W środowisku lektorów jpjo zgłaszany jest jednak postulat, aby już na poziomie A1 nauczać prawidłowej artykulacji samogłosek nosowych we wszystkich pozycjach, co zasadniczo pozostaje w zgodzie z ogólnymi zaleceniami: „Uczący się na poziomie A1 powinni: poprawnie wymawiać samogłoski (...)" (Janowska i in. 2011, s. 34).

Wydawać by się mogło, że postulat ten znajduje także oparcie w naukowych ustaleniach. Anita Lorenc bowiem, powołując się na wyniki badań m.in. Johna Lavera, Alaina Marchala czy Iana Maddiesona, wskazuje, że „fonologiczny kontrast pomiędzy samogłoskami ustnymi i nosowymi odnajdowany jest w około jednej czwartej języków świata (22,4\%)”, a „nosowość jest jednym z aspektów artykulacji wokoidów, odnajdywanym w niemal każdym języku świata” (szczególnie ze względu na procesy antycypacyjne przed spółgłoskami nosowymi) (Lorenc 2016, s. 53-54), np. francuskim, portugalskim, hindi. Można by więc przyjąć, że co najmniej jeden na czterech cudzoziemców uczących się języka polskiego jako obcego potencjalnie ma w swoim inwentarzu fonemów takie, które mogą mu pomóc w opanowaniu realizacji wspomnianych polskich dźwięków ${ }^{2}$, a jednak tak nie jest. Najważniejsze w początkach nauczania cudzoziemców jest przede wszystkim przyzwyczajenie studentów do tego, że litera <ą > odpowiada

\footnotetext{
1 Określenia $t z w$. samogłoski nosowe, realizacje $\langle a\rangle,\langle\varphi\rangle$ itp. stosowane są zarówno ze względu na przyjęte podejście (brak synchronii w realizacji liter $\langle a ̨\rangle,\langle e ̨\rangle$ ), jak i wymogi stylistyczne.

2 Większą trudnością dla znaczącej liczby uczących się są sposoby ich pisemnego odwzorowania niż ich artykulacja. Nie jest to miejsce na przytaczanie zasad zapisu $\langle a ̨>,<e ̨>$, lecz prawidła odnaleźć można m.in. u Markowskiego (2006); Karpowicza (2009); w Zasadach pisowni i interpunkcji (Polański 2008).
} 
w pierwszej fazie artykulacji głosce [o], której wymowa kojarzona jest raczej

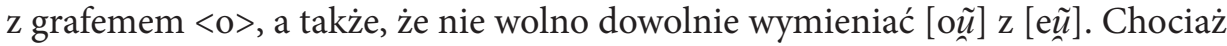
najistotniejszym zadaniem dydaktycznym na poziomie A1 jest niedopuszczenie do mylenia samogłosek nosowych lub ich całkowitej denazalizacji, to jednak zachęcanie do opanowywania sposobów wymowy mniej lub bardziej zbliżonych do rodzimych artykulacji także warte jest przemyślenia, niezależnie od tego, że poprawna realizacja tych głosek jest wymagana dopiero od poziomu B1 (Janowska i in. 2011). Skoro zatem za wzorcową realizację liter $<a ̨>,<e ̨>$ przed spółgłoskami frykatywnymi od początku nauki języka wielu lektorów uznaje wyłącznie wymowę z tylnym, nielabializowanym glajdem nosowym, zaczęto się zastanawiać, na ile nauczyciele są w stanie każdorazowo taką wymowę zdekodować (jeśli weźmie się pod uwagę np. liczne wpływy rodzimej artykulacji uczących się na wszystkie głoski w wypowiadanych wyrazach). Akustycy bowiem twierdzą, że percepcyjna analiza sygnału mowy jest bardzo zindywidualizowana, a „duże różnice w formie sygnału mogą być subiektywnie niedostrzegane lub akceptowane jako granice normy, podczas gdy w innym przypadku nawet drobne rozbieżności pomiędzy sygnałami stanowią kryterium do ich różnicowania i są podstawą do dyskwalifikacji jednego z nich jako formy patologicznej" (Kapusta 2000, za: Kleśta 2004, s. 106).

Wobec powyższego uznano, że w ramach badań fonodydaktycznych warto przyjrzeć się właśnie ocenom poszczególnych realizacji $<a ̨>,<e ̨>$ produkowanych przez różnych cudzoziemców posługujących się polszczyzną na poziomie A1. O ich odsłuch i decyzję odnośnie do ich poprawności poproszono doświadczonych lektorów jpjo pracujących w Łodzi ${ }^{3}$.

\subsection{Charakterystyka uczących się języka polskiego cudzoziemców}

Próbki wymowy cudzoziemców z poziomu Al uzyskano w czerwcu 2017 r. w Centrum Nauczania Języków Obcych Uniwersytetu Medycznego w Łodzi. Wszyscy uczestnicy badania uczyli się języka polskiego jako obcego przez jeden rok akademicki w wymiarze 50 godzin. Badania objęły rozmaite realizacje

Należy w tym miejscu podkreślić, że celem badań nie było wykazanie niekompetencji biorących w nich udział lektorów (udowodnienie niedostatków w kryterium oceniania, kłopotów ze słuchem itp.), ale próba obiektywnego wykazania, z jakich powodów ocena poszczególnych wymówień nastręcza tylu trudności. Nauczyciele języków obcych w trakcie pojedynczej lekcji, szczególnie na poziomie początkowym, wielokrotnie muszą podejmować decyzje, czy przykładowo poprawić uczącego się (błąd wymowy zakłócił komunikację), czy też pozwolić mu kontynuować wypowiedź (deformacja czy substytucja dźwięku nie wpłynęła na proces porozumiewania się). Tym bardziej autorka tekstu chciałaby serdecznie podziękować wszystkim nauczycielom, którzy odważyli się wziąć udział w opisanych badaniach. 
głoskowe ${ }^{4}$, lecz dla potrzeb niniejszego artykułu przytaczane są wyłącznie informacje dotyczące dźwiękowych realizacji liter $\langle a ̨\rangle,\langle e ̨\rangle$. Poniżej znajdują się dane losowo dobranych ${ }^{5} 23$ badanych (16 kobiet i 7 mężczyzn) z 18 krajów (Anglia, Arabia Saudyjska, Francja, Ghana, Indie, Irak, Kamerun, Liban, Malezja, Namibia, Niemcy, Nigeria, Norwegia, Palestyna, Polska ${ }^{6}$, Serbia, Szwecja, USA), którzy jako języki ojczyste wymienili 15 języków świata (angielski z wpływami hausa i joruba, angielski amerykański, angielski brytyjski, angielski i hindi ${ }^{7}$, angielski i oshiwambo, angielski i pendżabski, arabski, birmański, francuski, niemiecki, norweski, paszto, polski, serbski, tamilski).

Próbki wymowy analizowano akustycznie oraz audytywnie. Opis poszczególnych metod i analiz znajduje się w odpowiednich fragmentach artykułu.

\subsection{Charakterystyka lektorów (Polaków)}

Do udziału w eksperymencie zaproszono ośmiu lektorów języka polskiego jako obcego uczących w Studium Języka Polskiego dla Cudzoziemców w Łodzi (2 osoby), w Centrum Nauczania Języków Obcych Uniwersytetu Medycznego w Łodzi (4 osoby) oraz prowadzących lekcje w różnych, innych niż wyżej wymienione, łódzkich placówkach (2 osoby). Wszyscy lektorzy mają doświadczenie w pracy z cudzoziemcami na poziomie A1. Pięciu respondentów od dziesięciu lat pracuje w zawodzie, pozostali wykazali co najmniej pięcioletni staż zawodowy. Trzeba dodać, że jeden z lektorów skomentował swój słuch jako niedostatecznie dobry ze względu na problemy laryngologiczne (niedosłuch nie został jednak potwierdzony). Cztery osoby zajmują się niemal wyłącznie nauczaniem grup początkujących.

\section{Badania audytywne}

Eksperyment składał się z trzech badań audytywnych, których głównym celem było znalezienie odpowiedzi na pytanie, czy z punktu widzenia metodyki

\footnotetext{
4 Badaniom podlegały różne głoski języka polskiego, m.in. również samogłoski ustne, spółgłoski trzech szeregów, $[\mathrm{r}]$ czy [x]. Wiele z nich postrzega się jako o wiele trudniejsze w realizacji i istotniejsze komunikacyjnie niż analizowane na potrzeby niniejszego tekstu tzw. samogłoski nosowe. Postanowiono jednak pochylić się i nad tym problemem, ponieważ to właśnie te dwie głoski mają tak zaskakująco negatywną opinię dotyczącą trudności w zakresie artykulacji.

5 Pełny zakres badań objął 30 osób.

6 Dla wewnętrznego sprawdzenia rzetelności odpowiedzi wśród próbek znalazły się też nagrania rodzimego użytkownika języka.

7 Osoby dwujęzyczne wielokrotnie podawały dwa języki jako język ojczysty - nie umiały zdecydować, który z nich jest pierwszy, wobec czego w metryczkę wpisano oba.
} 
nauczania języka polskiego uzasadnione jest korygowanie wymowy cudzoziemców na poziomie A1 w zakresie realizacji dźwiękowej liter $\langle$ ą $\rangle,\langle$ ę $\rangle$, jeśli produkują oni po segmencie ustnym głoski jakąkolwiek nosowość (spółgłoskową lub niespółgłoskową). Uznano, że aby na to pytanie odpowiedzieć, należy najpierw sprawdzić, jakie trudności napotykają nauczyciele języka polskiego jako obcego przy ocenie wymówień tych samogłosek i czy przez wpływ wielu zmiennych (np. interferencji, niewyraźnej wymowy, ograniczonego czasu na odsłuch itp.) są oni w stanie zawsze precyzyjnie określić, czy cudzoziemiec artykułuje nosowość w jakikolwiek sposób, który zadowala ich na danym poziomie biegłości. Dopiero w dalszej kolejności można rozpocząć rozważania nad określeniem typów tejże nosowości ${ }^{8}$ W związku z tym pojawia się pytanie, czy ocena typu nosowości w ogóle jest możliwa w sytuacji lekcyjnej, czy lektorzy w ogóle są w stanie każdorazowo precyzyjnie to ocenić.

\subsection{Metodologia}

\subsubsection{Badanie wstępne - eksperyment nr 1}

Pierwszym eksperymentem objęto wszystkich nauczycieli. Polegał on na zaznaczeniu znakami + / - w odpowiedniej rubryce pod nagraniem, czy artykulację dźwiękową liter $<$ ą $>$, <ę $>$ w wyrazach uznają za prawidłową czy nieprawidłową (w wypadku odpowiedzi negatywnej proszeni byli o komentarz w dowolnej formie $)^{9}$. W ten sposób sprawdzono artykulację dwu wyrazów: ksiąz$k a$ i mężczyzna ${ }^{10}$, wypowiedzianych przed 20 obcokrajowców, co dało łącznie 40 realizacji.

8 Autorka podjęła próby prowadzenia takich badań. Obejmują one uczących się z językami pierwszymi: angielskim, niemieckim, norweskim i libańskim (pierwsze teksty są w druku).

9 Nagrania można było odsłuchać w programie Windows Media Player (formularze zostały przesłane do lektorów drogą elektroniczną).

10 Wybór wyrazów do wymówienia przez cudzoziemców motywowany był głównie wysoką frekwencją słów książka i mężczyzna - podawane są one od początkowego poziomu nauczania A1 i często wykorzystywane na zajęciach, a więc potencjalnie uczący się powinni być $\mathrm{z}$ nimi osłuchani (powinny być też wielokrotnie wykorzystywane $\mathrm{w}$ materiałach do ćwiczeń poprawnej wymowy). Po roku - mimo że to dopiero 50 godzin języka polskiego dla opisywanych grup - powinny być względnie opanowane. Badania niestety nie obejmowały mowy spontanicznej, a jedynie odczyt, lecz po wstępnym zapoznaniu się z materiałem słownym. Głównym powodem takiego postępowania były ograniczenia czasowe i warunki lokalowe. 
Tabela 1. Odpowiedzi lektorów (realizacja prawidłowa / nieprawidłowa) ${ }^{11}$

\begin{tabular}{|c|c|c|c|c|c|c|c|c|c|c|c|c|c|c|c|c|}
\hline \multicolumn{10}{|c|}{ Odpowiedzi lektorów } \\
\hline & \multicolumn{10}{|c|}{ ksiażka } \\
\hline & N1 & N2 & N3 & N4 & N5 & N6 & N7 & N8 & N1 & N2 & N3 & N4 & N5 & N6 & N7 & N8 \\
\hline 1. & + & - & + & + & - & + & + & + & - & - & - & + & - & - & - & + \\
\hline 2. & - & - & + & - & - & - & - & - & & - & - & - & - & - & - & - \\
\hline 3. & - & - & + & - & - & - & - & - & & - & - & - & - & - & - & - \\
\hline 4. & + & - & + & + & - & + & + & + & & - & - & - & - & - & - & - \\
\hline 5. & - & - & - & + & - & + & - & + & & - & - & - & - & - & - & - \\
\hline 6. & - & - & - & - & - & - & - & + & & - & - & - & - & - & - & - \\
\hline 7. & + & - & + & - & - & - & + & + & + & - & + & - & - & - & + & + \\
\hline 8. & - & - & + & + & - & - & - & + & & - & - & & - & - & - & - \\
\hline 9. & - & - & + & - & - & - & - & + & & - & - & & - & - & - & - \\
\hline 10. & - & - & - & + & - & - & - & - & & - & - & - & - & - & - & - \\
\hline 11. & - & - & - & + & & - & - & - & & - & - & - & - & - & - & - \\
\hline 12. & + & + & + & + & + & + & + & + & - & - & - & - & + & - & - & - \\
\hline 13. & - & - & + & + & - & - & - & + & - & - & - & - & - & - & - & + \\
\hline 14. & - & - & + & - & - & - & - & - & - & - & - & & - & - & - & - \\
\hline 15. & + & + & + & + & - & + & - & + & + & + & + & + & - & + & + & + \\
\hline 16. & - & - & + & - & - & - & - & + & - & - & - & & - & - & - & - \\
\hline 17. & - & - & + & - & - & - & - & + & - & - & $+/-$ & + & - & - & - & + \\
\hline 18. & - & - & - & - & - & - & - & + & - & - & - & + & - & - & - & + \\
\hline 19. & - & - & - & + & - & + & + & + & - & - & - & - & - & - & - & + \\
\hline 20. & - & - & $+/-$ & + & - & - & - & - & - & - & - & - & - & - & - & - \\
\hline
\end{tabular}

Źródło: oprac. własne

Ważne były komentarze, w których respondenci wyjaśniali swoje opinie, zwykle informując, że słyszą wymowę asynchroniczną charakterystyczną dla pozycji przed spółgłoskami zwarto-wybuchowymi (np. [on], [eń]), połączenia typu [ou] lub [05], a także że doszło do częściowej bądź całkowitej denazalizacji. Wiedzieli jednak, że w tej pozycji nosowość wyrażana jest inaczej (tylnym nosowym nielabializowanym glajdem), dlatego uznawali tego rodzaju realizacje za niepoprawne.

11 Znak „+” oznacza realizację prawidłową, a znak „-" realizację nieprawidłową. Nieoznaczone pole wyraża brak odpowiedzi, zwykle podparty komentarzem typu: „tu się zastanawiam, nie potrafię zdecydować, czy dobrze, czy źle” (N5). Poszczególnym lektorom przyporządkowano symbol N (nauczyciel) wraz z kolejnym numerem. 
Przykładem kontrolnym był numer 15, ponieważ były to realizacje rodzimego użytkownika języka i lektorzy, poza dwojgiem (N5 oraz N7), uznali je za prawidłowe. Pojawiły się też komentarze: „rodzimy użytkownik języka?”, „wykonanie podręcznikowe”, „niepotrzebna intonacja wznosząca”. Dołączenie do badań rodzimej artykulacji miało na celu sprawdzenie, czy respondenci rzeczywiście polegają wyłącznie na słuchu i odnoszą się do aktualnie wysłuchiwanych produkcji, czy też sugerując się doświadczeniem, zakładają wyłącznie realizacje (z)modyfikowane (wyraz książka wypowiedziany był wzorcowo, zaś mężczyzna z błędną akcentuacją).

Dodatkowo, już po wypełnieniu ankiet, do wszystkich respondentów skierowano pytanie: Czy wysłuchane artykulacje, które są nieprawidłowe - wyłącznie pod względem realizacji nosowości, zaaprobowaliby na poziomie początkowym A1? Wszyscy lektorzy gotowi byli zaakceptować wysłuchane wypowiedzi na tak niskim poziomie nauczania polskiego. Symptomatyczna jest opinia lektora N2, który stwierdził, że skłonny jest akceptować uchybienia, „póki z książki nie wyjdzie księżyc”, co należy odnieść do zaleceń, by na tym poziomie nauczania skupić się na podstawowym zadaniu, tj. wykształceniu u studentów umiejętności dokładnego rozróżnienia głoski przedniej od tylnej. Komentarze innych lektorów wyrażały podobny sens, m.in.: „wystarczyłoby mi cokolwiek, co ma element nosowy (może to być samogłoska plus spółgłoska nosowa)”, na poziomie A „może nawet do zaakceptowania byłyby formy bez jakiejkolwiek nosowości [meszczyzna] (...) To zależałoby od kontekstu” (N1), „Na A1 przyjęłabym tylko kryterium zrozumienia wyrazu (cudzoziemiec mówi, ja i inni rozumieją, co mówi)” (N3). Opinie te zdają się potwierdzać założenie badań - że na poziomie A1 to różnicowanie tylnej od przedniej samogłoski wraz z rezonansem nosowym, np. w postaci spółgłoski nosowej (niekoniecznie glajdu nosowego), są wystarczające komunikacyjnie.

\subsubsection{Badania dodatkowe}

Aby potwierdzić wyniki poprzedniego eksperymentu i sprawdzić, czy/w jakich kontekstach najczęściej lektorzy słyszą nosowość (niezależnie od tego, czy wiedzą, jaki wyraz jest wymawiany), zaproponowano dwa badania dodatkowe. Ośmioro przebadanych respondentów podzielono na dwie równe podgrupy, a każdej przekazano inną ankietę.

\section{Eksperyment 2a}

Pierwszy z eksperymentów polegał na wyborze z dwu proponowanych sylab tej, która została zrealizowana przez cudzoziemca. Wymowa była zapisana slawistycznym alfabetem fonetycznym, który wszyscy nauczyciele znali. Sylaby wyekscerpowano z wyrazów: mężczyzna (5 razy), książka (6 razy), czeszę ( 3 razy) się (2 razy), czarna (3 razy), herbatę (1 raz) - różnice w sylabach w tabeli wynikały $\mathrm{z}$ rzeczywistych fonetycznych realizacji. Wszystkie nagłosowe sylaby z wyrazów 
książka i mężczyzna pochodzą z pierwszego eksperymentu. Większość pozostałych słów realizowali ci sami cudzoziemcy, dla lepszej weryfikacji dodano jednak jeszcze trzy nowe osoby (ze względu na ciekawą warstwę brzmieniową nagrań), ponadto punkty nr 2 i 13 to ta sama realizacja, choć raz bez ostatniej głoski (przykład kontrolny). Celem dokonanych zmian, zwłaszcza zaś dodania sylab wygłosowych, było przyjrzenie się, czy realizacje w tej pozycji nie wpływają w jakiś znaczący sposób na liczbę odpowiedzi sugerujących ich poprawność.

Tabela 2. Badanie sylabowe

\begin{tabular}{|c|c|c|c|c|c|}
\hline \multicolumn{6}{|c|}{ Która sylaba została wymówiona? } \\
\hline 1. & [meũs] & [mes] & 11. & [śễu & [śe] \\
\hline 2. & [kśoũušs] & [kśoš $]$ & 12. & [ńoũ $]$ & [ńo] \\
\hline 3. & [meũus $]$ & {$[\mathrm{meš}]$} & 13. & [kśoũ $]$ & [kśo] \\
\hline 4. & {$[\check{s} \mathrm{e} \tilde{u}]$} & {$[\check{s} \mathrm{e}]$} & 14. & [kśeũus] & [kśeš $]$ \\
\hline 5. & [no $\tilde{u}]$ & [no] & 15. & [śe ũ ] & [śe] \\
\hline 6. & [kśoũuš] & [kśoš $]$ & 16. & [čeũ] & {$[\check{c} \mathrm{e}]$} \\
\hline 7. & [meüčc] & {$[\mathrm{mec}]$} & 17. & [kśoũ $]$ & [kśo] \\
\hline 8. & {$[\check{s} \mathrm{e} \tilde{u}]$} & {$[\check{s} \mathrm{e}]$} & 18. & [no $\tilde{u}]$ & [no] \\
\hline 9. & [kśoũ $\tilde{s}$ ] & [kśoš $]$ & 19. & [me ũšc] & [meš $]$ \\
\hline 10. & [meñšs] & {$[\mathrm{mes}]$} & 20. & [teũ ] & [te] \\
\hline
\end{tabular}

Źródło: oprac. własne

Jak widać na poniższym wykresie, respondenci znacznie różnili się co do oceny wybrzmienia nosowości. Tylko w przykładzie nr 12 wszyscy czworo udzielili takiej samej odpowiedzi. Najczęściej artykulację z cechami nosowości słyszał lektor N6 (11/20 razy), najrzadziej zaś lektor N3 (5/20 razy).

Wykres 1. Badanie sylabowe - odpowiedzi lektorów

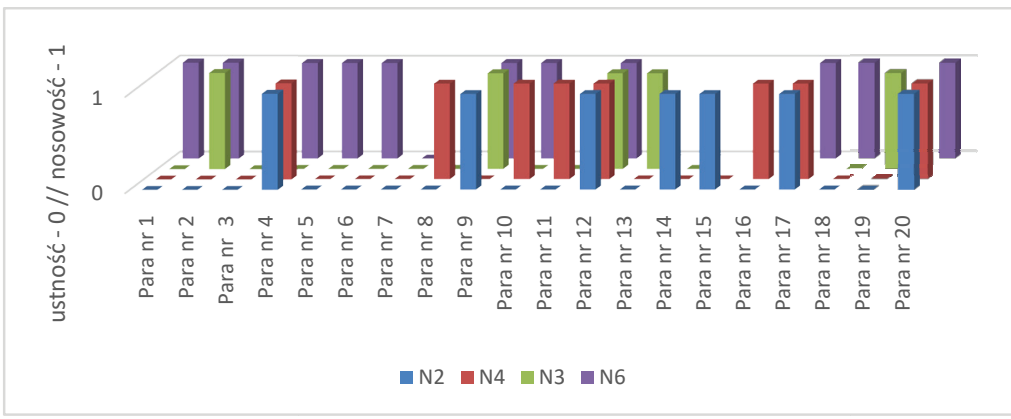

Źródło: oprac. własne 
Uznano za zasadne przyjrzenie się odpowiedziom potwierdzającym nosowość w kontekście pierwszego eksperymentu, wobec czego porównano jedenaście par nr: 1, 2, 3, 6, 7, 9, 10, 13, 14, 17, 19 z odpowiednimi nagraniami i ocenami nosowości. W wypadku wyrazu książka korelowały ze sobą następujące nagrania: para nr 2 - nagranie książka3, para nr 6 - książka13, para nr 9 - książka1, para nr 13 - książka3, para nr 14 - książka11, zaś para nr 17 - książkal6.

Wykres 2. Badanie dodatkowe (książka) - odpowiedzi czworga lektorów

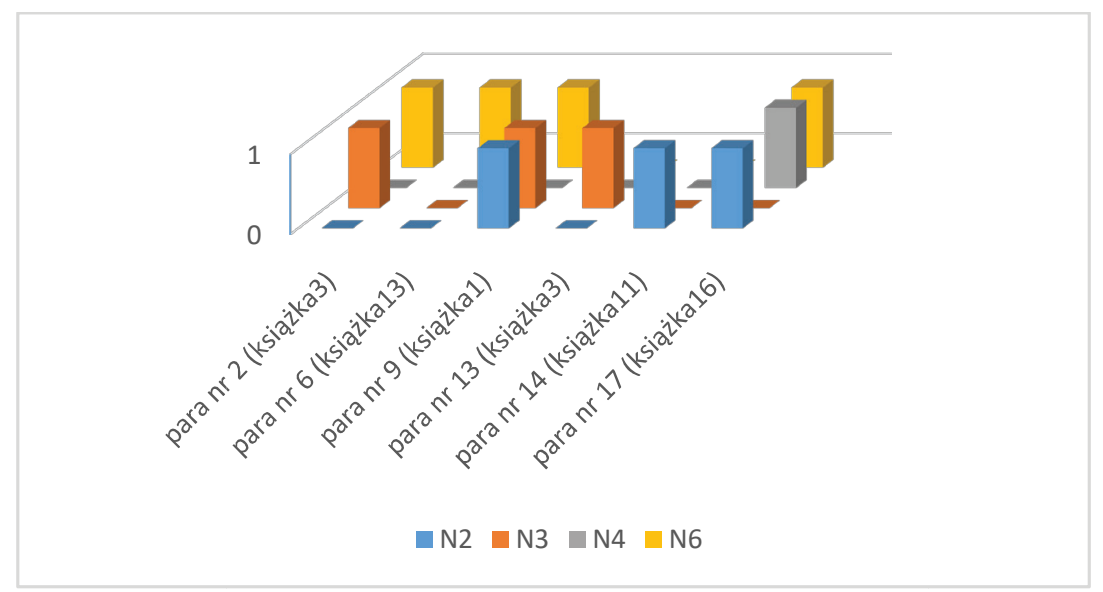

Źródło: oprac. własne

W zadaniu z sylabami odpowiedzi były następujące: troje lektorów za artykulację z nosowością uznało pary nr 9 i 17, dwoje określiło tak parę nr 2, pozostałe zaś pary po jednej osobie. Co ciekawe, wśród analizowanych przykładów N2 usłyszał nosowość w parach: 9, 14 i 17, lektor N3 w parach 2, 9, 13, lektor N4 tylko w parze nr 17, a N6 w parach nr 2, 6, 9, 17. Porównanie powyższego wykresu $\mathrm{z}$ wykresem dla tych samych nagrań i tych samych lektorów z badania pierwszego pozwala dostrzec różnice między odpowiedziami. Właściwie tylko N3 wykazał się pewną konsekwencją działania. N2 słyszał nosowość w sylabach, lecz w ogóle nie odnotował jej w wyrazach, N6 cztery razy usłyszał ją w sylabach, a tylko raz w pełnym wyrazie, przeciwną tendencją wykazał się N4 - tylko raz zaznaczył ją w sylabie, a dwukrotnie w słowach. 
Wykres 3. Badanie wstępne (książka) - odpowiedzi czworga lektorów ${ }^{12}$

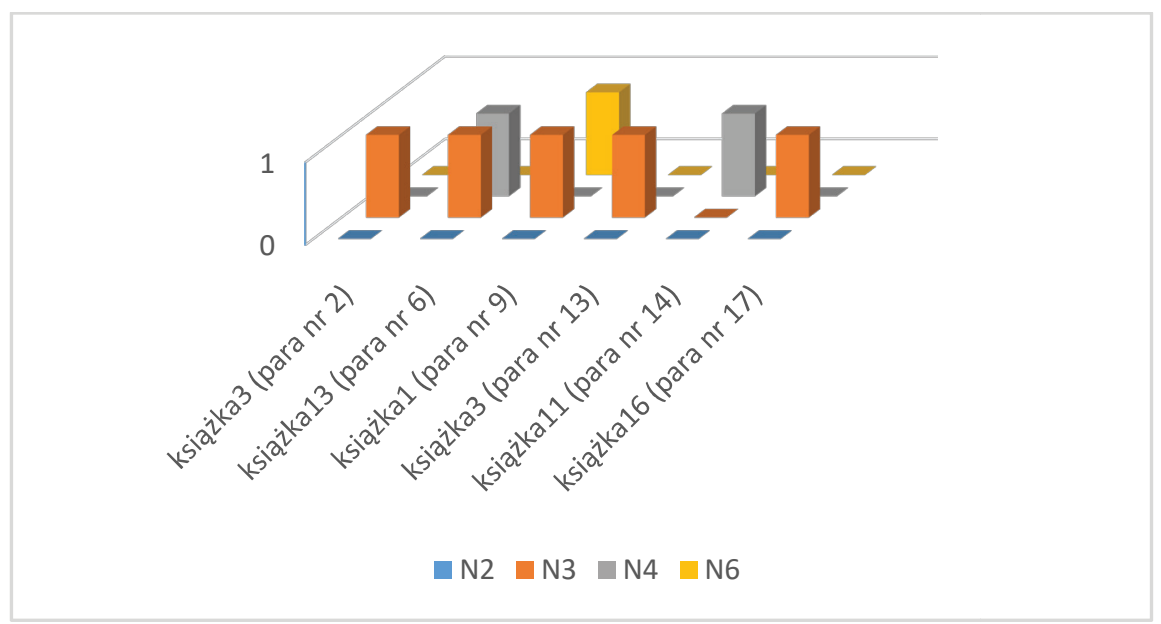

Źródło: oprac. własne

Co prawda w tym badaniu polecenie brzmiało: Która sylaba jest realizowana?, nie było to zaś wartościowanie: Proszę zaznaczyć znakiem + I - w odpowiedniej rubryce (pod nagraniem), czy artykulację dźwiękowa liter $\langle q\rangle,\langle\rho\rangle>w d w u w y$ razach uznaja Państwo za prawidłowa czy nieprawidłowa, jak to miało miejsce $\mathrm{w}$ wypadku pierwszego badania, a jednak wybierając sylaby $\mathrm{z}$ nosowością, badani niejako przyznawali im status poprawnych, ponieważ i tu odnosili brzmienie poszczególnych wyrazów do wiedzy, jaką posiadają na temat realizacji głoski w konkretnej pozycji.

Częściej za niepoprawne uznawano całe wyrazy niż same sylaby, o czym świadczą dane: 11 zaaprobowanych sylab wobec 8 wyrazów, z czego tylko cztery odpowiedzi się pokryły; trzy lektora N3 i jedna lektora N6. I choć to uproszczenie, można przyjąć, że o częstszym odrzuceniu przesłuchanych całych słów niż wyłącznie samych sylab decydowały inne uchybienia artykulacyjne w artykułowanych wyrazach. Taki wniosek jest oczywisty, jeśli weźmiemy pod uwagę fakt, że w wyrazie książka oprócz trudności związanej z nosowością zmianom artykulacyjnym ulegały pozostałe głoski, co zapewne rzutowało na ocenę globalną wykonania. W badaniu sylabowym proszono jedynie o wybór wyprodukowanej sylaby.

W badaniu pierwszym lektorzy niekiedy za pomocą alfabetu fonetycznego zapisywali to, co usłyszeli i np. N2, który podczas oceny pełnych wyrazów żadnego z wymienionych nie uznał za poprawny, dopisał komentarze typu: [kśonska

12 Na wykresie zaznaczono wartością 0 odpowiedzi z badania wstępnego oceniające wypowiedź jako niepoprawną, a cyfrą 1 te uznane za prawidłowe (dotyczy tylko tych czworga lektorów, którzy wypełniali oba opisane kwestionariusze). 
/ kśonczka / kśonszka] ${ }^{13}$. Takie realizacje rzeczywiście nie pozwoliłyby na uznanie wymowy wyrazu za poprawną, jednak nie przez brak glajdu nosowego, a ze względu na substytucję w dwu pierwszych realizacjach spółgłoski [2] na [s] lub [1]. Jednak, co istotniejsze, zapis w tabeli z sylabami zakładał wyłącznie brzmienie $\mathrm{z}$ wymową prawidłową w tej pozycji lub wersję odnosowioną, np. [kśoũ 2] / [kśo2]. Żaden z przebadanych nie skomentował tego, nie zanegował i nie podważył. Oczywiście bierze się pod uwagę, że było to wyrazem grzeczności względem przeprowadzającego badanie (lektorzy nie chcieli podważać kompetencji badacza), mimo to można przyjąć, że przynajmniej część z lektorów rzeczywiście nie zwróciła na to uwagi. Wydaje się, że samo zaistnienie dowolnego typu nosowości (poza siłą sugestii) niejako usprawiedliwia brak wymowy wzorcowej i audytywnie może być uznane za wystarczające, a może nawet prawidłowe - rzecz jasna w odniesieniu do cudzoziemców, szczególnie na początkowym etapie nauczania (a przecież badani byli poinformowani o tym, że wysłuchują wypowiedzi uczących się na poziomie A1). I choć badania potwierdzające tę obserwację powinny być zakrojone na większą skalę, także z pytaniem o dyskryminację sylab z zastosowaniem zapisu ortograficznego, to wyniki opisanych badań zdają się umożliwiać postawienie tak odważnej tezy. Potwierdzają to też komentarze typu „delikatnie słychać «n», ale myślę, że wymowa może być zaakceptowana” (N6 w odniesieniu do nagrania książka12).

W przypadku wyrazu mężczyzna pięć nagrań wyizolowano i wprowadzono do tabeli ze zgłoskami: para nr 1 - mężczyzna13, para nr 3 - mężczyzna1, para nr 7 mężczyzna3, para nr 10 - mężczyzna16, a para nr 19 - mężczyzna11. Jak widać na poniższym wykresie, tylko w jednym przypadku uznano wymowę za poprawną.

Wykres 4. Badanie dodatkowe (mężczyzna) - odpowiedzi czworga lektorów

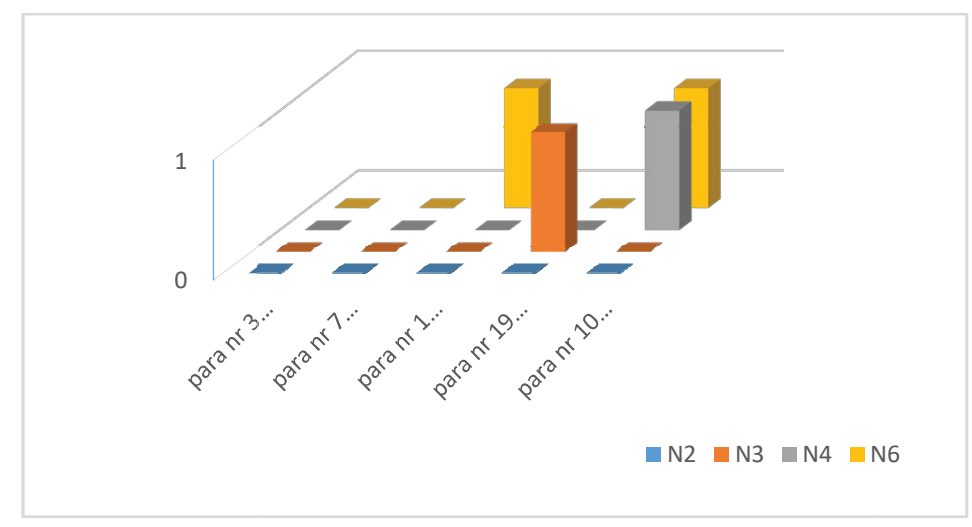

Źródło: oprac. własne

13 Zapis oryginalny (tu i we wszystkich innych cytowanych komentarzach). 
W badaniu dodatkowym odpowiedzi kształtowały się w następujący sposób: nosowość zaaprobowano w parach nr 1, 10 i 19, z czego dwa razy zrobił to lektor N6, raz lektorzy N3 i N4. W badaniu pierwszym tylko raz (spośród lektorów przebadanych testem dodatkowym sylabowym) odnotowano w wybranych przykładach prawidłową realizację (N4).

Wykres 5. Badanie wstępne (mężczyzna) - odpowiedzi czworga lektorów

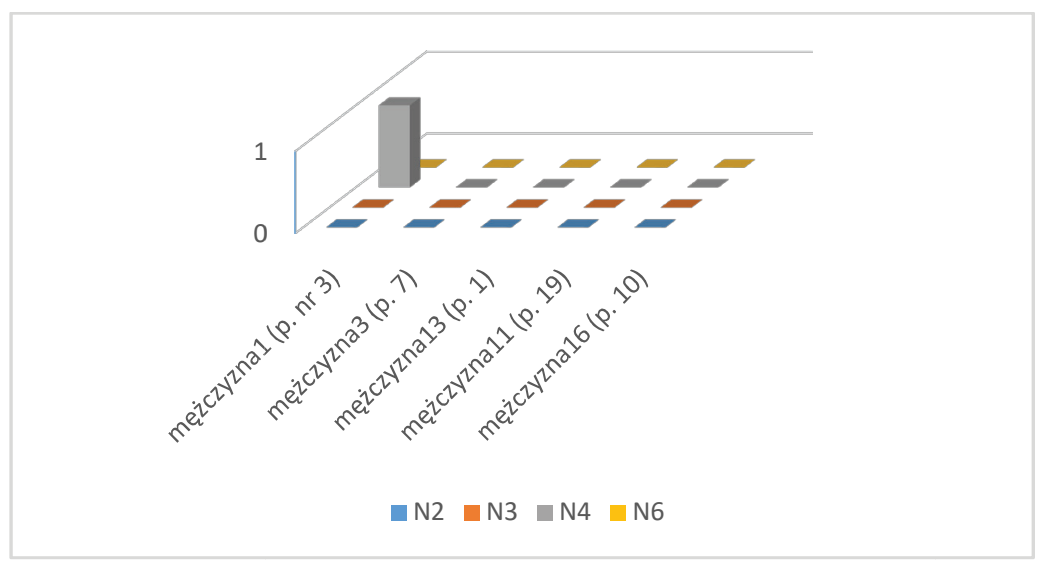

Źródło: oprac. własne

W związku z tym żaden z lektorów nie potwierdził w badaniu kontrolnym swojej opinii aprobującej wymowę. Podtrzymano niejako decyzje o jej braku, a więc i nieprawidłowej realizacji w 15 przykładach na 20.

Ze względu na długość wyrazu i wystąpienie po sobie sekwencji [ ̌̌čc trudniejszej niż $[s \mathrm{k}]$ z pierwszego przykładu, w tym wypadku substytucje, deformacje i elizje w realizacjach były liczniejsze i intensywniej wypływały na opinie ankietowanych. Jest to też zapewne powód nie tak wielkich jak poprzednio różnic w ocenie lektorów.

\section{Eksperyment 2b}

W ramach drugiego eksperymentu zadaniem pozostałych czworga lektorów było dokonanie deskrypcji 20 usłyszanych wyrazów (próbki wgrane w kwestionariusz w dokumencie Word). Były to słowa: mężczyzna, książka, dziewięć, dziesięć, czarną, czeszę się (po 2 realizacje), a także czeszę, cześć, herbatę, śniadaniowe, proszę, poproszę, butelkę, myślę (po jednej realizacji). Tworzą one kilka kategorii: realizacje liter $<a ̨>,<e ̨>$ w śródgłosie przed spółgłoską szczelinową twardą (mężczyzna, książka), w wygłosie (butelkę, (po)proszę, czeszę (się), czarna, herbatę, myślę), z nosowością konsonantyczną (dziewięć, dziesięć), samogłoska ustna jako paronim do słowa $\mathrm{z}$ nosowością (cześć) i samogłoska ustna po spółgłosce 
nosowej środkowojęzykowej lub przed nią (śniadaniowe) - kontrolnie (bywa, że są to w różnych językach warunki wystarczające do uzyskania nazalizacji).

Wykres 6. (Nie)rozpoznane wyrazy

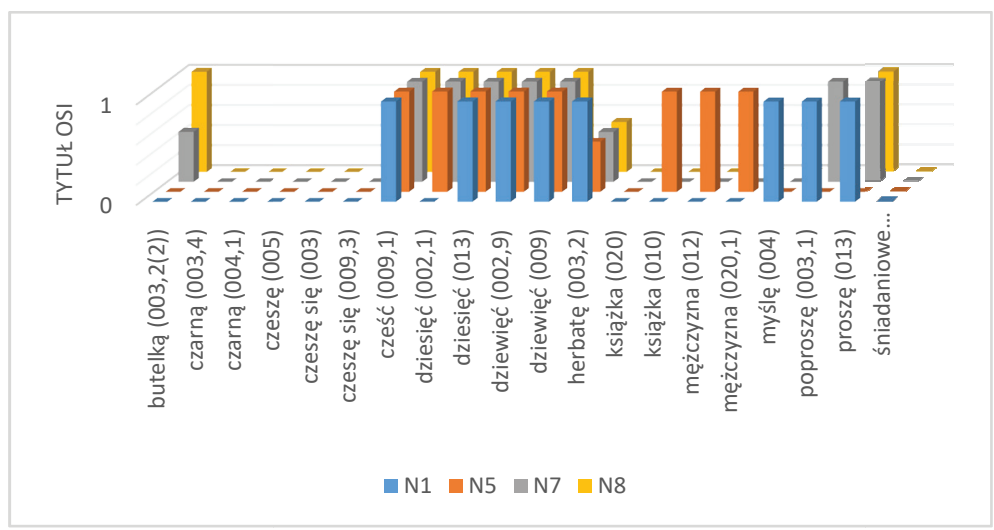

Źródło: oprac. własne

W pierwszej kolejności sprawdzono, czy da się zrozumieć bez kontekstu sytuacyjnego realizacje słów z poziomu A1. Nagrania dobrane były losowo, więc w puli do odsłuchu znalazły się zarówno wyraźne i dość prawidłowo wyprodukowane słowa (12), jak i mocno zmodyfikowane (8). Do tych z licznymi zmianami, utrudniającymi czy uniemożliwiającymi ich jednoznaczne zrozumienie należą: czeszę, czarną $(004,1)$, wszystkie wykonania czeszę się, książka i mężczyzna (celowo znalazły się tu wersje wcześniej odsłuchiwanych słów). Należy jednak podkreślić, że ich zrozumienie w kontekście byłoby możliwe, nie odbiegały one bowiem od typowych realizacji, z którymi lektorzy mierzą się na zajęciach. Brak otoczenia, konsytuacji czy deiktyzmu wyraźnie jednak uniemożliwił ich percepcję. Warto więc szczególnie docenić odpowiedzi lektora N5, który prawidłowo rozpoznał aż 9 wyrazów, z czego 3 były niewyraźnie wyartykułowane.

Niestety ze względu na to, że tylko N5 rozpoznał dwukrotnie realizacje wyrazu mężczyzna i jedną z dwu wyrazu książka, nie da się tych wyników w sposób rzetelny odnieść do badania pierwszego. Jak się zdaje, główną tego przyczyną była liczba dźwięków, które ulegały deformacjom lub substytucjom, choć podczas przygotowywania zbioru nagrań nie wydawały się one autorce badań tak trudne czy niejednoznaczne. Więcej wniosków można by otrzymać, gdyby słowa książka i mężczyzna stanowiły większość spośród proponowanych w ostatnim eksperymencie wyrazów. Uznano jednak, że uwzględnienie w badaniu innych słów pokaże, czy w wygłosie nosowość jest przez lektorów częściej / rzadziej percypowana (a zgodnie z normą w tej pozycji artykulacja tzw. samogłosek nosowych może być taka sama, choć przy <ę> dochodzi często do odnosowienia). 
Należy także zaznaczyć, że tym razem - w przeciwieństwie do badania wstępnego - wszyscy respondenci zrezygnowali $z$ alfabetu fonetycznego i zapisywali słowa ortograficznie (polecenie brzmiało: Proszę zapisać usłyszane wyrazy. W przypadku ich niezrozumienia prosze o zaznaczenie tego znakiem - .). Nie zdarzyły się komentarze dotyczące wymowy (poprawności czy jej braku), nosowości itp. (nie były też wymagane). Kilkukrotnie w odpowiedzi znalazła się inna forma gramatyczna niż ta, w jakiej rzeczywiście wyraz został artykułowany (patrz: wykres 6.): N7 zapisał herbata i butelkom, N5 i N8 - herbata (odpowiedzi zaznaczone na wykresie w połowie długości słupka). Te zmiany, mimo że nieliczne, potwierdzają trudności w percepcji tych głosek także w wygłosie (wygłos zwykle sprzyja redukcjom).

Wyrazy rozpoznane przez wszystkich to: cześć, dziesięć (013) oraz obie realizacje liczebnika dziewięć. Nie są to słowa o większej frekwencji na tym poziomie nauczania języka polskiego w porównaniu z pozostałymi wyrazami użytymi w badaniu. Tzw. samogłoski nosowe otoczone są w nich spółgłoskami środkowojęzykowymi i przedniojęzykowo-dziąsłowymi, a więc często zniekształcanymi na początku nauki. Dodatkowo wymienione liczebniki to wyrazy uznawane za jedne z najtrudniejszych w wymowie dla obcokrajowców, a jednak zostały prawidłowo usłyszane. Nie da się po takiej próbce badawczej wyciągnąć miarodajnych wniosków, ogólnie uznać jednak można, że - omijając wyrazy rzeczywiście zniekształcone - właściwie rozpoznane zostały te, w których $\langle$ ą $\rangle,\langle$ ę $\rangle$ pojawiało się jak najdalej od nagłosu wyrazu.

\section{Badania akustyczne}

Wymowę cudzoziemców nagrywano za pomocą komputera HP ProBook 430 G3 wprost do programu Praat $^{14} \mathrm{z}$ wykorzystaniem wbudowanego mikrofonu, wobec czego ostatecznie część nagrań ze względu na sprzęt i różnego rodzaju dodatkowe i niezamierzone szumy nie podlegało analizie akustycznej, mimo że wykorzystano je w badaniach odsłuchowych, ponieważ były wystarczająco wyraźne.

Dla potrzeb niniejszego artykułu zdecydowano, że badania akustyczne obejmą dwa wyrazy $\mathrm{z}<$ ą $>\mathrm{i}<\mathrm{e}>\mathrm{w}$ pozycji przed spółgłoską szczelinową twardą $[\mathfrak{s}]$ : mężczyzna i książka. Za pomocą programu Praat dokonano segmentacji sygnałów mowy, a następnie i ich analizy. Ze względu na to, że badaniom podlegały dwa słowa o podobnej sekwencji głosek badanych sylab: $<$ męż $>$ i $<$ książ $>$ (tzw. samogłoska nosowa w śródgłosie przed $[\mathfrak{s}]$ ), zdecydowano się wyłącznie na anotację w ich obrębie. W podziale sugerowano się zarówno obrazem z oscylogramu, jak i ze spektrogramu. Budowa sylab pozwoliła na dość precyzyjne postawienie

\footnotetext{
14 Profesjonalny program pobrany ze strony http://www.fon.hum.uva.nl/praat/download_win.html
} 
granic między głoskami - ze względu na charakterystyczną akustycznie spółgłoskę szumową oraz odznaczające się regularnością przebiegu dźwięczne samogłoski. Dla oceny różnic pomiędzy realizacją ustną a ustno-nosową samogłosek postanowiono skorzystać $\mathrm{z}$ oznaczania formantó $\mathrm{w}^{15}$. Ze względu między innymi na niesynchroniczną i dyftongiczną realizację nosowości, koartykulację czy pozycję $\mathrm{w}$ wyrazie trudno niekiedy zaobserwować granice między fazami dźwię$\mathrm{ku}^{16}$, wobec czego materiał badawczy odniesiono do charakterystycznych zjawisk towarzyszących wymowie tzw. samogłosek nosowych, widocznych w analizie akustycznej i opisywanych wcześniej w literaturze m.in. przez takich badaczy jak M. Zagórska-Brooks (1964) (samogłoski nosowe przed trącymi są o wiele dłuższe niż odpowiadające im ustne $\mathrm{w}$ tej samej pozycji, ich wartość $\mathrm{F}_{2}$ obniża się). Dla potrzeb niniejszego tekstu wystarczające okazało się sprawdzenie wyłącznie dwu pierwszych formantów i iloczasu samogłosek.

Uznano, że wartościowe będzie przebadanie akustyczne przede wszystkim tych realizacji, które zostały przez lektorów rozpoznane jako prawidłowe, a przy tak małej próbie badawczej za statystycznie ważne uznano przykłady, co do których minimum 4 nauczycieli (50\%) nie miało wątpliwości i uznało je za poprawne (w tabeli $\mathrm{nr} 1$ zostały pogrubione). W wypadku wyrazu ksiażka były to realizacje numer: $1,4,7,12,15,19$, natomiast odnośnie do wyrazu mężczyzna - przykłady numer 7 i $15^{17}$.

Segmentacji dokonano w programie Praat i na jej podstawie ustalono, że iloczas realizacji <ą> w nagraniu oznaczonym jako książkal wynosił ok. $178 \mathrm{~ms}$, w ksiązka4 ok. 174 ms, w książka7 - 295 ms, w ksiązka12 - 206 ms, w ksiązka15 - 207 ms, a w książka19 - 151 ms (a więc wszystkie wartości bardzo przewyższają typowe dla samogłosek $100 \mathrm{~ms}$ ), co świadczy o tym, że nie są to czyste realizacje ustnej głoski [o], ale połączenia jej z dodatkowym elementem. Dla porównania przytoczyć warto, że według najbardziej aktualnych i najbardziej precyzyjnych, jak dotąd, wyników badań przeprowadzonych przez A. Lorenc średni iloczas realizacji <ą> przed spółgłoskami trącymi wewnątrzwyrazowo „wynosi 249 ms (250 ms u kobiet i 243 ms u mężczyzn)” (Lorenc 2016, s. 326). Co najważniejsze, we wszystkich przykładach uznanych przez respondentów za właściwie zrealizowane pod względem nosowości odsłuch pokrywa się z analizą akustyczną.

15 Rozumiane jako składowe częstotliwości dźwięków mowy, które uległy największemu wzmocnieniu w jamach nasady w wyniku zjawiska rezonansu akustycznego. Dla percepcji samogłosek wystarczają zwykle $\mathrm{F}_{1} \mathrm{i} \mathrm{F}_{2}$, i te tylko zostały zbadane.

16 Autorka badań nie dysponowała też narzędziem, które by precyzyjnie oddzieliło kanał ustny od nosowego podczas nagrywania.

17 W ramach badań do niniejszego artykułu, ze względu na długość tekstu, przytacza się tylko analizy dla pierwszego z wyrazów. 
Początkowo dla wszystkich wyrazów mierzono formanty tzw. samogłosek nosowych na podobnym odcinku - ok. $20 \mathrm{~ms}$, bez początku i końca głoski, by zmniejszyć wpływy koartykulacji - niestety uzyskane wartości okazywały się wielokrotnie silnie odstawać od polskich ustaleń (Kleśta 1998; Gonet 1993) (1) $^{1}$. Zdecydowano się więc na pomiar dłuższy i wyliczanie średniej na podstawie listy formantów. Trzy pierwsze nagrania rejestrowały głosy kobiece, a trzy ostatnie głosy męskie - głównym odniesieniem stały się więc wyniki podawane przez Janusza Kleśtę.

Tabela 3. Średnie wartości częstotliwości $\mathrm{F}_{1}$ i $\mathrm{F}_{2} \mathrm{w}$ przebadanych nagraniach

\begin{tabular}{|c|c|c|c|c|c|}
\hline \multicolumn{7}{|c|}{ kobiety } \\
\hline \multicolumn{2}{|c|}{ ksiażka1 } & \multicolumn{2}{c|}{ książka4 } & \multicolumn{2}{c|}{ ksiązka7 } \\
\hline $\mathrm{F}_{1}$ & $\mathrm{~F}_{2}$ & $\mathrm{~F}_{1}$ & $\mathrm{~F}_{2}$ & $\mathrm{~F}_{1}$ & $\mathrm{~F}_{2}$ \\
\hline 956 & 1251 & 697 & 1206 & 967 & 1164 \\
\hline \multicolumn{6}{|c|}{ Norma dla polszczyzny wg Kleśty } \\
\hline $\mathrm{F}_{1}$ & \multicolumn{3}{|c|}{619} & $\mathrm{~F}_{2}$ & 1194 \\
\hline
\end{tabular}

\begin{tabular}{|c|c|c|c|c|c|}
\hline \multicolumn{7}{|c|}{ mężczyźni } \\
\hline \multicolumn{2}{|c|}{ ksiażka12 } & \multicolumn{2}{c|}{ ksiażka15 } & \multicolumn{2}{c|}{ ksiażka19 } \\
\hline $\mathrm{F}_{1}$ & $\mathrm{~F}_{2}$ & $\mathrm{~F}_{1}$ & $\mathrm{~F}_{2}$ & $\mathrm{~F}_{1}$ & $\mathrm{~F}_{2}$ \\
\hline 596 & 1536 & 522 & 1009 & 694 & 1085 \\
\hline \multicolumn{6}{|c|}{ Norma dla polszczyzny wg Kleśty } \\
\hline $\mathrm{F}_{1}$ & \multicolumn{3}{|c|}{491} & $\mathrm{~F}_{2}$ & \multicolumn{2}{c|}{1025} \\
\hline
\end{tabular}

Źródło: oprac. własne

Należy zaznaczyć, że wartości formantów tylko ogólnie (relacyjnie) odnoszono do polskich norm ${ }^{19}$. Szczególne różnice widać w przypadku F1, mniej znaczące

18 W literaturze można spotkać różne wartości średnie czy granice wartości, w których obrębie formanty powinny się znaleźć. Rozbieżności wynikają z wielu czynników, m.in. wieku przebadanych osób, podziału u Kleśty na głosy kobiece i męskie, indywidualnych cech. Język w trakcie artykulacji samogłosek jest względnie swobodny, wobec czego każdorazowo ich artykulacja nawet przez jedną osobę będzie dawała nieco inne pomiary (stąd wyniki często uwzględniają wariantywność i wartości podawane są jako przybliżone i uśrednione). Przykładowo W. Gonet opisuje średnią wartość F1 jako $518 \mathrm{~Hz}$, a F jako $1075 \mathrm{~Hz}$ (1993).

19 Celem badań nie było precyzyjne scharakteryzowanie jakości głosek, czyli stwierdzanie, na ile są podobne lub się różnią od typowo polskich realizacji (m.in. na podstawie wartości formantów). Badania artykułowanych przez cudzoziemców (posługujących się określonymi językami pierwszymi) głosek względem polszczyzny to osobny problem badawczy - tutaj tylko wspomniany (patrz: cele i wnioski). 
lub żadne są dla F2 (przypuszczać można, że w głównej mierze wynika to z wyartykułowania przez cudzoziemców głosek jedynie zbliżonych do polskich samogłosek $^{20}$, o nieco innym jednak stopniu otwarcia jamy ustnej). Dzięki tej drugiej wartości (informacja o ułożeniu masy języka) dało się jednak zaobserwować, że w nagraniu książka12 wyartykułowana została głoska zbliżona do [e]: średnie $\mathrm{F}_{1}$ dla mężczyzn wynosi 474, a $\mathrm{F}_{2}$ - 1750. Choć żaden z lektorów takiej uwagi nie odnotował - a pojawiały się tego rodzaju sugestie względem innych nagrań (np. komentarz N6 dla nagrania książka20) - to jednak ponowny i wielokrotny odsłuch całego słowa pozwala uznać, że doszło do substytucji.

Ponadto obraz oscylogramów ${ }^{21}$ wykazywał po pierwszej - zawsze ustnej - fazie głoski różne przebiegi. Zwykle były nietypowe np. dla spółgłosek nosowych (jak przy rozłożeniach artykulacji na [on]), amplituda była bowiem niska / coraz niższa (a nie wysoka), szybko tracił się też obraz dźwięczności (charakterystyczny w przebiegu tych spółgłosek, choć nie zawsze przez cały czas ich trwania) bądź niemal od razu go nie było (co potwierdzał też spektrogram) - to może być jednak wpływ koartykulacji, ponieważ kolejne głoski w wyrazie są bezdźwięczne. Wielokrotnie zdarzało się, że obraz jednoznacznie wykazywał głoskę [n] lub [m], mimo że lektorzy uznali wymowę za prawidłową ${ }^{22}$.

Rys. 1. Przykładowa segmentacja - nagranie książka1

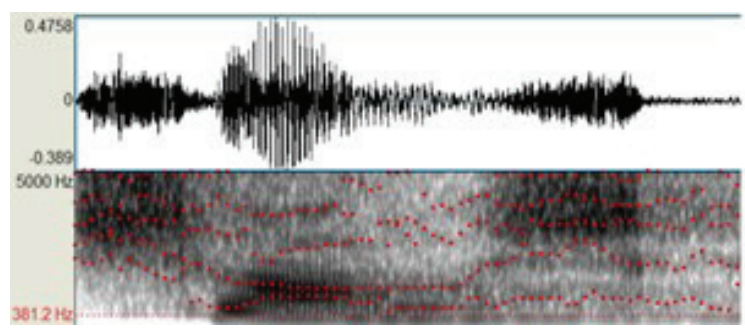

Źródło: oprac. własne

Niedostrzeżenie przez nauczycieli zamiany głoski z realizacji <ą $>$ na $<$ ę $>$ w przykładzie książka12 zainspirowało do sprawdzenia, w ilu jeszcze nagraniach zaszła taka substytucja i ilu lektorów ją skomentowało. Analiza spektrogramów wykazała, że jeszcze pięciokrotnie doszło do zamiany dźwięków mowy. Cztery pierwsze nagrania to produkcje głosów kobiet, ostatni głos jest

\footnotetext{
20 Nagrania w analizowanej kolejności to artykulacje obcokrajowców z: Arabii Saudyjskiej, Niemiec, Serbii, Iraku, Polski i Palestyny.

21 Ze względu na ograniczenia związane z liczbą stron artykułu umieszcza się tylko wnioski $\mathrm{z}$ jednym przykładowym zdjęciem dokonanych analiz.

22 Wnioski m.in. na podstawie wartości formantów F1 i F2, które według Jassema (1973) wynoszą odpowiednio: $320 \mathrm{~Hz}$ i $1100 \mathrm{~Hz}$ dla [n] oraz $300 \mathrm{~Hz}$ i $750 \mathrm{~Hz}$ dla [m].
} 
męski. W nagraniu w książka5 $\mathrm{F}_{1}$ wyniosło $630 \mathrm{~Hz}$, a $\mathrm{F}_{2}-2279 \mathrm{~Hz}$, w ksiażka6 $\mathrm{F}_{1}-609 \mathrm{~Hz}, \mathrm{~F}_{2}-2408 \mathrm{~Hz}$, książka10 $\mathrm{F}_{1}-561 \mathrm{~Hz}, \mathrm{a} \mathrm{F}_{2}-2060 \mathrm{~Hz}, \mathrm{w}$ książka20 $\mathrm{F}_{1}-654 \mathrm{~Hz}, \mathrm{~F}_{2}-1987 \mathrm{~Hz}$, zaś w książka11 $\mathrm{F}_{1}-409 \mathrm{~Hz}$, natomiast $\mathrm{F}_{2}-2070 \mathrm{~Hz}$. Wszystkie substytucje autorka badań potwierdziła odsłuchowo.

Wykres 7. Dostrzeżone substytucje

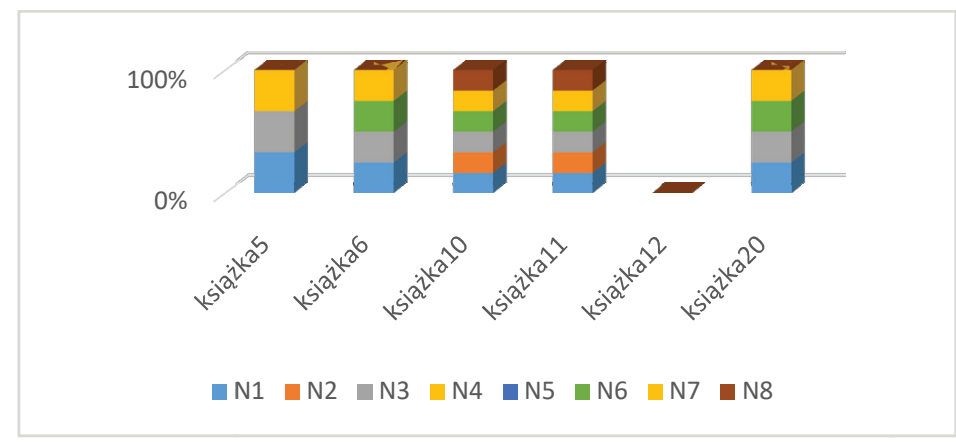

Źródło: oprac. własne

Jak wynika z powyższego wykresu, w nagraniach nr 10 i 11 sześcioro respondentów spostrzegło substytucję, nikt zaś nie spostrzegł jej w nagraniu nr 12 (również w nagraniu nr 5 zmiana okazała się trudna do wychwycenia). Badany N4 nagrania nr 5, 10, 11 i 20 oznaczył jako artykulację prawidłową, N2 wszystkie oznaczył jako nieprawidłowe, lecz substytucje odnotował tylko w przykładach $\mathrm{nr} 10$ i 11, N5 oznaczył je jako nieprawidłowe (nie skomentował realizacji nr 11), nigdzie jednak nie odnotował zamian głosek. Lektor N1 wszystkie oznaczył jako błędne, przy nagraniu nr 5 skomentował „Inna barwa samogłoski?”, a przy pozostałych zapisał fonetycznie brzmienie z [e]. Lektorzy N3 i N7 również skomentowali wszystkie artykulacje, dopisując komentarze typu: „Słyszę raczej ę”, „Słyszę coś między ą a ę” i wymowę z [e]. N8 substytucje zaznaczył dla nagrania nr 10 i 11, a ostatni z badanych nagranie numer 5 oznaczył jako prawidłowe, jednak już pozostałe komentował np.: „Zamiast ą słyszę ę (en)”. Można na tej podstawie wysnuć wniosek, że skoro usłyszenie zamiany samogłoski z tylnej na przednią bywa tak trudne nawet dla doświadczonych lektorów (m.in. ze względów antycypacyjnych, ponieważ innych różnic się spodziewają), to słuchowe wychwycenie sposobu realizacji asynchronii podczas produkcji tzw. samogłosek nosowych może być jeszcze trudniejsze.

\section{Wnioski}

Zebranie danych z badań audytywnych uznaje się za zasadne, gdyż rozważania dotyczące normy są z gruntu subiektywne - zwłaszcza że rozpatruje się normę glottodydaktyczną (Chomicz-Jung 1990), zmienną i nie dość sprecyzowaną. 
Należy więc zadać pytanie, czy skoro chcemy wymagać od cudzoziemców wzorcowych realizacji nosowości, to czy potrafimy je odpowiednio słuchowo ocenić? Poziom początkowy znajomości języka obcego charakteryzuje się w warstwie fonicznej szeregiem czynników (takich jak interferencja, nie dość wykształcony słuch mowny, niewyćwiczona pamięć fonetyczna, niestaranna artykulacja), które silnie wpływają na możliwości dekodowania wypowiadanych wyrazów także przez natywnych użytkowników języka - zwłaszcza że w omawianych eksperymentach słowa, a nawet sylaby, pozbawiane były kontekstu. Jak pokazały wyniki tych kilku krótkich badań, problem ten jest niedoceniany i wydaje się, że tym bardziej warto zacząć zwracać na niego uwagę - szczególnie w kontekście tworzenia kryteriów oceny wypowiedzi ustnej, np. podczas egzaminów certyfikatowych na poziomie początkowym. Potwierdzeniem takiego podejścia okazał się nieprzewidziany

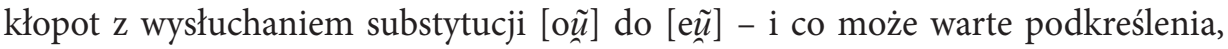
podczas przygotowywania formularzy dla lektorów także i autorka badań nie spostrzegła tego podczas pierwszych odsłuchów dla przykładu nr 12. Dlatego też zdecydowano się na wprowadzenie do badań dodatkowej analizy akustycznej, a porównanie oceny respondentów z wynikami obiektywnego badania uważa się za wystarczająco rzetelne potwierdzenie próby badawczej - choć, rzecz jasna, niewielkiej.

Opisane badania są początkiem, pierwszą próbą zebrania danych, by móc w sposób miarodajny spróbować odpowiedzieć na postawione w tekście pytania. Zdaje się jednak, że można wysnuć pierwsze wnioski płynące z badań dotąd przeprowadzonych. Po pierwsze, skoro na poziomie A według kryteriów stawianych przez ESOKJ czy Programy nauczania języka polskiego jako obcego zapisane jest, że uczący się mają poprawnie artykułować wszystkie samogłoski (Janowska i in. 2011), ale dopiero od B1 wymieniane są osobno tzw. samogłoski nosowe, to norma glottodydaktyczna powinna uwzględniać na poziomie początkowym - także w śródgłosie przed trącymi - różne realizacje. Wyartykułowanie dowolnego typu nosowości (np. spółgłoski nosowej o podobnym, choć nie zawsze takim samym miejscu artykulacji do kolejnej głoski) jest lepszym i skuteczniejszym komunikacyjnie postępowaniem niż produkcja wyłącznie ustna, nie wspominając o zmianie samogłoski (z przedniej na tylną i odwrotnie). Tezę tę podkreślają wyniki badań porównawczych: różnice między tym, co słyszeli i aprobowali lektorzy, a informacjami płynącymi z analiz akustycznych. Szczególne rozbieżności pokazało też akceptowanie nosowości w sylabach, a nieakceptowanie w wyrazach - silnie zniekształcanych przez inne zjawiska fonetyczne. Co należy podkreślić, wszyscy przebadani lektorzy wykazali się właściwym według autorki podejściem do istoty błędów na poziomie A (aprobata nieidealnych wymówień), ich dobór w badaniu nie był jednak zupełnie przypadkowy - są to pracownicy, doktoranci i byli doktoranci Zakładu Lingwistyki Stosowanej i Kulturowej Uniwersytetu Łódzkiego. Inspiracją do przeprowadzenia eksperymentów były jednak głosy płynące ze środowiska, 
w tym liczne komentarze zgłaszane przez lektorów, podkreślające wagę prawidłowego artykułowania $<$ ą $>$, $<e ̨>$ już na poziomie A1.

Głównym postulatem po przeprowadzeniu analiz jest stworzenie zestawienia, a nawet korpusu typów wymówień dla poszczególnych pozycji, wraz z informacjami, które narodowości prezentują je najczęściej (relacja norma językowa a norma glottodydaktyczna), a przede wszystkim - do jakiego poziomu biegłości językowej są one akceptowalne na podstawie kryterium zrozumienia wyrazu/ intencji nadawczej. Uważa się, że takie wymienienie wariantów wraz z ich podziałem na poziomy nauczania byłoby niezwykle cenne dla wszystkich lektorów języka polskiego jako obcego.

\section{Bibliografia}

Biernacka, M. (2016). Znajdź z polskim wspólny język. Fonetyka w nauczaniu języka polskiego jako obcego. Łódź: Wydawnictwo Uniwersytetu Łódzkiego.

Chomicz-Jung, K. (1990). Norma glottodydaktyczna i jej rola w procesie glottodydaktycznym, Przeglad Glottodydaktyczny, 11, 21-38.

ESOKJ - Europejski system opisu kształcenia językowego: uczenie się, nauczanie, ocenianie (2003). Tłum. W. Martyniuk, Rada Europy. Warszawa: Wydawnictwo CODN.

Gonet, W. (1993). Próba określenia normy wymowy polskich samogłosek ustnych. W: S. Grabias (red.), Opuscula Logopaedica in honorem Leonis Kaczmarek (232-253). Lublin: Wydawnictwo UMCS.

http://www.fon.hum.uva.nl/praat/download_win.html

Janowska, I., Lipińska, E., Rabiej, A., Seretny, A., Turek, P. (red.) (2011). Programy nauczania języka polskiego jako obcego. Poziomy A1-C2. Kraków: Księgarnia Akademicka.

Karpowicz, T. (2009). Kultura języka polskiego. Wymowa, ortografia, interpunkcja. Warszawa: Wydawnictwo Naukowe PWN.

Kleśta, J. (1998). Lingwistyczne i paralingwistyczne zastosowanie akustyczno-fonetycznej bazy danych samogłosek języka polskiego, Technologia Mowy i Języka, 2, 47-64.

Kleśta, J. (2004). Analiza akustyczna polskich spółgłosek trących bezdźwięcznych realizowanych przez dzieci niesłyszące, Audiofonologia, 26, 105-118.

Lorenc, A. (2016). Wymowa normatywna polskich samogłosek nosowych i spółgłoski bocznej. Warszawa: Dom Wydawniczy Elipsa.

Markowski, A. (red.) (2006). Wielki słownik poprawnej polszczyzny. Warszawa: Wydawnictwo Naukowe PWN.

Polański, E. (red.) (2008). Zasady pisowni i interpunkcji. Warszawa: Wydawnictwo Naukowe PWN.

Zagórska-Brooks, M. (1964). Nasal Vowels in Contemporary Standard Polish, International Journal of Slavic Linquistics and Poetics, 8, 102-109. 


\section{Streszczenie}

Większość współczesnych opracowań fonetycznych, powołując się na obiektywne badania akustyczne, przyjmuje asynchroniczną i dwu-, trzy- lub czterosegmentalną artykulację samogłosek reprezentujących grafemy $\langle a ̨\rangle,\langle e ̨\rangle$. Mimo to nadal silnie zakorzenione są próby nauczania polskiej wymowy cudzoziemców, które uwzględniając różnice wynikające z pozycji głoski w wyrazie, nie przyjmują jednak poglądów o braku synchronicznej artykulacji tzw. samogłosek nosowych m.in. w wygłosie czy przed dźwiękami frykatywnymi niepalatalnymi. Biorąc pod uwagę wykładniki normy glottodydaktycznej oraz wyniki badań audytywno-akustycznych przeprowadzonych na potrzeby niniejszego tekstu, proponuje się ponowne zweryfikowanie wymagań względem mówiących po polsku nie-Polaków, skoro sami rodzimi użytkownicy języka prezentują różne realizacje. 